\title{
Kepemimpinan Yesus Kristus sebagai Model Dasar Kepemimpinan Kristen Berdasarkan Matius 20:20-28
}

\author{
Firman Panjaitan \\ Sekolah Tinggi Teologi Tawangmangu \\ panjaitan.firman@gmail.com
}

\begin{abstract}
The leadership crisis is an actual problem in Indonesia, which can be seen from the arrest of several leaders by the Corruption Eradication Commission due to the weak leadership model of the leaders. The leadership of Jesus Christ is the answer to the current leadership crisis. In the midst of a leadership model that relies on power, position and tends to be self-oriented, Jesus' leadership model which is oriented towards a leaderservant pattern and is altruistic in nature becomes the way to answer the leadership crisis. The critical interpretation's method of the Bible which search for the meaning of the passage based on the existing text and 'sitz im leben', especially to Matthew 20:20-28, found a leadership model of Jesus that deserves to be followed and at the same time can be used as a guide for developing an appropriate and effective leadership model. The results of the study show that the leadership model of Jesus Christ in Matthew 20: 20-28 is leadership that has a vision and leadership ethics for the Kingdom of God, namely a leadership model that is pro-people and life (altruistic). Through the leadership model of Jesus Christ, one can lead effectively, efficiently and down to earth.
\end{abstract}

Keywords: Christian; Ethics of the Kingdom of God; Jesus Christ; Leadership; LeaderServant; Vision.

\begin{abstract}
Abstrak: Krisis kepemimpinan adalah masalah aktual di Indonesia, yang terlihat dari peristiwa tertangkapnya beberapa pemimpin oleh Komisi Pemberantasan Korupsi akibat lemahnya model kepemimpinan dari para pemimpin. Menghadapi hal ini, penulis melihat bahwa model kepemimpinan Yesus Kristus merupakan jawaban terhadap krisis kepemimpinan yang sedang terjadi. Di tengah model kepemimpinan yang mengandalkan kekuasaan, jabatan dan cenderung berorientasi pada diri sendiri, maka model kepemimpinan Yesus yang berorientasi pada pola pemimpin-pelayan dan bersifat altruistik menjadi sebuah 'angin segar' untuk menjawab krisis kepemimpinan. Dengan menggunakan metode tafsir kritis yang mencari makna perikop berdasarkan teks dan sitz im leben yang ada, khususnya Matius 20:20-28, ditemukan sebuah model kepemimpinan Yesus yang layak diteladani dan sekaligus dapat dijadikan panduan untuk mengembangkan model kepemimpinan yang tepat dan efektif. Hasil penelitian memerlihatkan bahwa model kepemimpinan Yesus Kristus dalam Matius 20:20-28 adalah kepemimpinan yang memiliki visi dan etika kepemimpinan Kerajaan Allah, yaitu model kepemimpinan yang berpihak pada sesama dan kehidupan (bersifat altruistik). Melalui model kepemimpinan Yesus Kristus, seseorang dapat memimpin dengan efektif, efesien dan membumi.
\end{abstract}


Kata Kunci: Etika Kerajaan Allah; Kepemimpinan; Kristen; Pemimpin-Pelayan; Visi; Yesus Kristus

$\begin{array}{llll}\text { Article History : } & \text { Received: 19-10-2020 } & \text { Revised: 16-12-2020 } & \text { Accepted: 18-12-2020 }\end{array}$

\section{Pendahuluan}

Pentingnya manajemen, yang merupakan salah satu alat dalam kehidupan organisasi terutama dalam bidang kehidupan manusia, selalu mendapat perhatian khusus dalam masalah kepemimpinan. Seorang pemimpin adalah motor penggerak dari usaha atau kegiatan untuk melaksanakan fungsi-fungsi manajemen, terutama dalam pengambilan keputusan dan kebijaksanaan yang dapat memermudah pencapaian tujuan dari organisasi secara efektif dan efisien. Berhasil tidaknya usaha pencapaian tujuan sangat ditentukan oleh kemampuan pemimpin yang memegang peranan penting dalam rangka menggerakkan orang-orang yang dipimpinnya, oleh sebab itu ketrampilan memimpin(leadership skill)harus dimiliki oleh seorang pemimpin. Pemimpin yang baik dituntut untuk bersifat luwes, mampu beradaptasi dengan lingkungan yang bergerak sangat dinamis, mengantisipasi berbagai perubahan, dan bersikap proaktif terhadap organisasi yang dipimpinnya.

Untuk menjadi pemimpin yang baik tidaklah mudah, diperlukan sebuah model yang mampu untuk menjadi teladan bagi kepemimpinan. Apalagi dewasa ini, khususnya di Indonesia, banyak terjadi krisis kepemimpinan yang mengakibatkan mundurnya, bahkan hancurnya, sendi-sendi kehidupan berorganisasi akibat ketiadaan keteladanan kepemimpinan yang tepat, ${ }^{1}$ dan krisis kepemimpinan ini sudah menggejala secara umum. Di lingkup pemerintahan pun krisis kepemimpinan terjadi, dan itu tampak dari tidak adanya teladan dari para pemimpin daerah yang mengalami OTT (Operasi Tangkap Tangan) oleh KPK (Komisi Pemberantasan Korupsi) akibat terlibat dalam tindak pidana korupsi. Tentunya hal ini sangat memrihatinkan, khususnya ketika seorang pemimpin yang seharusnya dapat menjadi teladan bagi orang-orang yang dipimpinnya (masyarakat) tetapi dalam kenyataannya mereka (para pemimpin) malah menjadi orang-orang yang melanggar setiap aturan dan kesepakatan yang ada di dalam sistem kehidupan bersama/bermasyarakat.Untuk mengatasi hal di atas, perlu dihadirkan sebuah model kepemimpinan yang dapat menjadi pedoman dan arah mengenai bagaimana memimpin yang benar, dan melalui model ini dapat dibangun budaya kepemimpinan yang tepat serta bermanfaat guna bagi kehidupan. Dalam hal ini penulis sangat terinspirasi dengan model serta gaya kepemimpinan yang telah dibangun

${ }^{1}$ Sandu Frunză, "Ethical Leadership, Religion and Personal Development in the Context of Global Crisis," Journal for the Study of Religions and Ideologies 16, no. 46 (2017): 4. 
oleh Yesus Kristus, sebagai seorang Pemimpin-Pelayan, seperti yang ditampilkan secara utuh dan sempurna melalui pemaparan yang transparan dan jelas oleh Alkitab. ${ }^{2}$

\section{Metode Penelitian}

Metode yang akan digunakan dapat memaparkan model kepemimpinan Yesus Kristus adalah metode tafsir kritis terhadap Alkitab, yaitu upaya untuk menemukan makna dari sebuah perikop dengan didasarkan atas latar belakang yang menginspirasi terbentuknya perikop tersebut. Metode ini akan digunakan secara khusus terhadap Matius 20:20-28, dan untuk mengarahkan penelitian tafsir terhadap perikop lain dari Alkitab dilakukan analisis terhadap berbagai bagian Alkitab yang menggambarkan tentang model kepemimpinan yang diajarkan melalui tindakan memimpin seperti yang dilakukan oleh Yesus Kristus. Oleh sebab itu, pembahasan Alkitab dengan menggunakan metode ini merupakan pembahasan yang lebih bersifat umum dan tematis, dalam arti pengambilan makna dari sebuah kejadian dalam Alkitab hanya dibatasi pada hal-hal yang menyangkut tentang model kepemimpinan yang dikembangkan oleh Yesus Kristus. Hasil dari analisis ini kemudian dijadikan sebuah pedoman untuk membangun model kepemimpinan Yesus Kristus yang dapat diimplementasikan ke dalam gaya kepemimpinan dewasa ini.

\section{Hasil dan Pembahasan}

\section{Dasar Alkitabiah Kepemimpinan Kristen}

Dalam pengamatan penulis, salah satu yang dapat dijadikan dasar Alkitabiah kepemimpinan Kristen adalah Matius 20:20-28. Memang ada banyak dasar Alkitabiah dari kepemimpinan Kristen, tetapi sengaja penulis menggunakan perikop di atas dengan alasan bahwa melalui perikop ini Yesus meletakkan sendi-sendi kepemimpinan yang sangat khas, yaitu kepemimpinan yang didasarkan atas kesediaan untuk melayani, dan hal ini dikontraskan dengan model-model kepemimpinan dunia. Melalui peletakan sendi-sendi kepemimpinan ini, Yesus sekaligus memproklamirkan model kepemimpinan yang dibangun-Nya melalui pelayanan yang dilakukan-Nya selama berkarya di dunia. Kisah dalam Matius 20:20-28 menceritakan tentang pertengkaran yang terjadi di antara para murid tentang siapa yang terbesar di antara mereka. ${ }^{3}$ Pertengkaran tersebut berkisar tentang siapa yang berhak menjadi yang terbesar di bumi, khususnya dalam sistem pemerintahan.

2Verne H. Fletcher, Lihatlah Sang Manusia: Suatu Pendekatan Pada Etika Kristen Dasar (Jakarta: BPK Gunung Mulia, 2007), 208-226; Yakob Tomatala, Par-Excellence Leadership: Memimpin Seperti Yesus Kristus (Jakarta: YT Leadership Foundation, 2013), 29.

3Peniel S D Maiaweng, “"Kebesaran Seorang Pemimpin, Suatu Refleksi Terhadap Matius 20:20-28”," in Kepemimpinan Kristen Yang Membumi, ed. Nasokhili Giawa (Jakarta: YT Leadership Foundation, 2017), 458. 
Awal pertengkaran mereka berasal dari permintaan ibu Yohanes dan Yakobus agar Yesus berkenan untuk menempatkan mereka berdua, kelak, duduk di sebelah kanan dan kiri Yesus ketika sudah berada di dalam Kerajaan Sorga (ay. 21). Permintaan ini adalah permintaan yang wajar, karena hal ini sangat berkaitan dengan janji Yesus yang mengatakan bahwa siapa pun yang percaya kepada Anak akan percaya kepada Bapa, dan barang siapa hidup di dalam Anak akan hidup pula di dalam Bapa. Jadi jika Anak, suatu saat, pergi ke rumah Bapa, maka setiap orang yang percaya juga akan pergi dan hidup di rumah Bapa (bdk. Yoh. 14:1-14). Jadi tidaklah berlebihan jika ibu dari kedua murid tersebut meminta dan mencoba mengingatkanYesus agar kedua anaknya duduk bersama dengan Yesus ketika sudah berada di rumah Bapa.

Permasalahan muncul ketika para murid yang lain menangkap permintaan ibu Yohanes dan Yakobus ini dalam perspektif yang berbeda. Mereka melihat dan menduga bahwa permintaan ibu Yohanes dan Yakobus ini sangat berkaitan dengan masalah kekuasaan dalam memerintah. Mereka menduga bahwa permintaan ini erat dengan keinginan untuk menjadi 'wakil' dari Yesus yang berkaitan dengan dimilikinya kekuasaan memerintah bagi kedua anaknya sebagai konsekuensi dari penempatan mereka di sisi kanan dan kiri Yesus. Inilah yang menjadi pangkal pertengkaran mereka, karena pada dasarnya para murid yang lain pun sangat menginginkan jabatan dan kuasa tersebut. Jadi pertengkaran ini hendak memerebutkan kuasa dan jabatan untuk memerintah dunia. Terjadi pergeseran pemahaman, yang semula ibu Yohanes dan Yakobus hanya meminta agar anak-anaknya dapat duduk di sisi kanan dan kiri Yesus ketika berada di rumah Bapa, namun pemahaman ini digeser oleh para murid lainnya menjadi kecurigaan bahwa ibu Yohanes dan Yakobus meminta agar kedua anaknya itu diangkat menjadi wakil Yesus untuk memerintah dunia.

Yesus melerai pertengkaran mereka dengan menjabarkan satu pandangan yang hendak menjungkirbalikkan pemahaman pemerintahan dan kepemimpinan dunia. Yesus hendak memerhadapkan model kepemimpinan dunia ini dengan model kepemimpinan dalam Kerajaan Sorga. Yesus mengungkapkan bahwa kebesaran pemimpin bukan terletak pada kekuasaan atau jabatan yang dimilikinya, yang digambarkan dalam pemahaman duduk di sebelah kanan dan kiri seorang Raja, melainkan terletak dalam kerendahan hatinya untuk melayani setiap orang yang dipimpinnya. ${ }^{4}$ Dalam terminologi kepemimpinan dunia (ay. 25), Yesus mengatakan bahwa kepemimpinan dunia berjalan dalam sistem memerintah dengan tangan besi dan para pembesar menjalankan kuasanya untuk menguasai yang dipimpinnya. Hal ini, kemudian, dikontraskan dengan kepemimpinan dalam sistem Kerajaan Sorga, di mana seorang pemimpin bukanlah bertujuan hendak menguasai yang dipimpinnya, melainkan melayani setiap orang yang dipimpinnya. Inilah perbedaan yang hakiki, yaitu antara

${ }^{4}$ Asi Vasudeva Reddy and A. V.S. Kamesh, "Integrating Servant Leadership and Ethical Leadership," Ethical Leadership: Indian and European Spiritual Approaches (London: Palgrave Macmillan, 2016), 108, https://doi.org/10/1057/978-1-137-60194-0_7. 
menguasai dan melayani. Menurut Yesus, seorang pemimpin yang besar adalah seorang pelayan, yaitu orang yang mengadakan pemeliharaan; yang mencukupi kebutuhan orang yang memerlukan bantuan; yang mengorbankan milik dan kepentingannya sendiri untuk kepentingan orang lain, yang memiliki sikap altruis (perhatian terhadap kesejahteraan orang lain tanpa memperhatikan diri sendiri) dan tidak egois (perhatian terhadap diri sendiri tanpa mau mempedulikan orang lain). Orang yang terkemuka adalah hamba, yaitu orang yang mengikatkan dirinya untuk mengabdi bagi orang lain, yang tidak berkuasa atas dirinya sendiri, yang taat, tunduk dan patuh pada aturan untuk melaksanakannya dengan sukacita dan sukarela, yang taat mengabdikan diri kepada siapa yang menjadi tuannya, dan yang tidak memertahankan gengsi untuk melakukan sesuatu bagi orang lain. ${ }^{5}$

Apabila dikaitkan dengan keberadaan Yesus, Ia sendiri mengatakan bahwa Ia adalah Pelayan dan Hamba (Mat. 12:18-21), yang tidak mementingkan diri-Nya sendiri dan mau berkorban bagi manusia. Yesus mengabdikan diri-Nya kepada Bapa dan menjadi Hamba yang menderita serta taat sampai mati di kayu salib untuk menyelamatkan manusia (bdk. Yes. 42:1-2). Keberadaan Yesus sebagai Pelayan dan Hamba, kemudian, diamanatkan kepada murid-murid-Nya agar mereka pun mengabdikan diri kepada Allah dan sesama dalam pelayanan. Dengan demikian Yesus hendak mengembangkan konsep dan model kepemimpinan yang baru, yang khas Kristus, yaitu kepemimpinan dengan prinsip pemimpin-pelayan, yang berorientasi pada identifikasi dan pemenuhan kebutuhan-kebutuhan orang lain, alih-alih sekadar berusaha memeroleh kekuasaan, kekayaan, dan ketenaran bagi diri sendiri. Seorang pemimpin-pelayan adalah orang yang sudah melupakan kepentingannya sendiri dan hidup untuk menyejahteraan hidup orang lain. ${ }^{6}$ Tegasnya, seorang pemimpin-pelayan adalah seorang pemimpin yang membumi dan mendunia; dan ini merupakan model kepemimpinan Kristen. ${ }^{7}$ Jadi bentuk kepemimpinan yang dikembangkan oleh Yesus adalah kepemimpinan yang berbasis pada kehidupan-Nya sebagai seorang Pelayan dan Hamba.

\section{Visi Kepemimpinan Kristen}

Syarat utama dalam kepemimpinan Kristen adalah memiliki visi, karena jika seorang pemimpin tidak memiliki visi maka ia tidak akan pernah menjadi pemimpin yang berhasil dan sekaligus menjadi pemimpin yang kerdil serta tidak berguna. Sebaliknya, jika seorang pemimpin mempunyai visi, ia akan menjadi pemimpin yang bisa mengarahkan setiap orang yang dipimpinnya menuju pada kehidupan yang lebih

\footnotetext{
${ }^{5}$ Maiaweng, “"Kebesaran Seorang Pemimpin, Suatu Refleksi Terhadap Matius 20:20-28"," 57-59.

${ }^{6}$ Daniel Nuhamara, "'Pentingnya Karakter Kepemimpinan Dalam Organisasi"," in Kepemimpinan Kristen Yang Membumi, ed. Nasokhili Giawa (Jakarta: YT Leadership Foundation, 2017), 33.

${ }^{7}$ Yakob Tomatala, Memimpin Seperti Yesus Kristus: Kepemimpinan Yang Par-Ekselens (Jakarta: YT Leadership Foundation, 2010), 12.
} 
baik, bahkan pemimpin yang bervisi adalah pemimpin yang mampu membaca serta mengantisipasi masa depan berdasarkan kemampuannya 'melihat' apa yang sekiranya akan terjadi. Seorang pemimpin harus memulai kepemimpinannya dengan menemukan terlebih dahulu visi bagi kepemimpinan yang diembannya, kemudian mengembangkannya dalam proses kepemimpinan yang dijalankannya dengan sepenuh hati. Visi perlu untuk ditemukan dan dikembangkan oleh seorang pemimpin karena merupakan elemen dasar yang akan menuntun seorang pemimpin hidup dan bekerja secara efektif dan efisien. Visi akan mengantar seorang pemimpin untuk mengarahkan kelompok, organisasi (formal maupun non-formal) menuju pada keberhasilan kinerja, kemaslahatan dan kelanggengan hidup. Visi adalah faktor penentu keberhasilan seorang pemimpin. Jika dikaitkan dengan kepemimpinan Kristen, hal ini menegaskan bahwa kepemimpinan Kristen harus memiliki visi kepemimpinan yang didasarkan, diterangi, didorong dan dikembangkan oleh kekuatan nilai-nilai Kristiani, dan ini akan menjadi sesuatu yang khas dalam mengembangkan seni kepemimpinan. ${ }^{8}$

Sebelum membicarakan lebih jauh mengenai visi sepemimpinan Kristen, terlebih dahulu perlu memahami makna dari kata 'visi'. Visi (Ing.: vision, visoum, atau Lat.: visio, visus, videre) memiliki arti dasar 'melihat', namun arti selengkapnya dari visi adalah tindakan atau kekuatan melihat dengan mata; atau kemampuan intuitif untuk melihat ke depan. ${ }^{9}$ Jadi visi merupakan sebuah kekuatan diri untuk melihat, mengimajinasi, serta memahami sesuatu yang tidak dapat dilihat oleh orang kebanyakan. Jika kata visi ini digabungkan dengan kata Kristen, menjadi visi Kristen, maka dapat dipahami bahwa visi Kristen adalah kemampuan untuk melihat keinginan suci yang disampaikan oleh Yesus Kristus, di dalam batin, guna menjawab setiap kebutuhan yang berkaitan dengan pemenuhan hidup seseorang atau setiap individu bagi diri maupun organisasi yang dipimpinnya; dengan kata lainAllah,di dalam Yesus Kristus, adalah sumber dan pemberi visi. Hal ini berarti bahwa kebenaran firman Allah merupakan kekuatan utama yang akan memimpin seorang pemimpin untuk mengetahui dan membongkar rahasia mengenai "sumber visi" dalam kepemimpinannya. Seorang pemimpin Kristen harus memiliki pergaulan yang erat dengan Allah, agar ia dapat memahami segala rahasia kepemimpinan yang ditulis oleh Allah di dalam dirinya dan ia senantiasaa menempatkan Allah dan firman-Nya sebagai sumber visi Kepemimpinannya.

Dalam pergaulan yang erat dengan firman Allah, seorang pemimpin Kristen akan memahami tujuan dari keberadaan setiap individu sehingga ia akan dapat memimpin dan mencapai tujuan akhir dari individu dan organisasi yang dipimpinnya, karena ia mengetahui bahwa visi kepemimpinan yang didasarkan pada Allah, sebagai sumber visi, merupakan tindakan kepemimpinan yang bersifat keseluruhan dan mencakup hal-hal yang dulu, sekarang dan akan datang. Dengan demikian kepemimpinan yang

8Yakob Tomatala, Anda Juga Bisa Menjadi Pemimpin Visioner Kiat Menemukan Dan Mengembangkan Visi Kepemimpinan (Jakarta: YT Leadership Foundation, 2005), 20-21.

${ }^{9}$ Ibid., 12-13. 
dikembangkan adalah kepemimpinan yang didasarkan atas kebenaran Allah yang bersifat objektif, profitable dan pragmatis dan sangat berguna bagi banyak orang, sekalipun visi yang dimaksud adalah visi pribadi. ${ }^{10}$ Dapat dikatakan bahwa visi kepemimpinan Kristen adalah visi yang altruistik karena senantiasaa membawa kebaikan dan kemanfaatan bagi banyak pihak.

Untuk menemukan visi kepemimpinan Kristen, hal utama yang harus dilakukan seorang pemimpin Kristen sebagai dasar kehidupannya adalah selalu memiliki waktu untuk berdoa, ${ }^{11}$ yaitu sebuah tindakan membuka komunikasi dengan Allah, Sang Sumber visi, dan mendengar apa yang dikehendaki Allah terhadap dirinya. Melalui doa perenungan instrospektif dapat dilakukan guna menemukan jawaban atas pertanyaan mengenai keinginan suci (visi) yang telah dihadirkan dan ditulis Allah di dalam batin. Perenungan introspektif ini akan memberi kemampuan untuk membuat sebuah perencanaan strateegis dan partisipatif untuk bisa memimpin dirinya dan organisasi yang dipimpinnya untuk menggapai kehidupan masa depan dengan didasarkan atas kerinduannya untuk bertindak dan melakukan segala hal yang bermanfaat bagi orang lain, dan semua ini ditujukan untuk memuliakan nama Allah, sebagai Sumber visi kepemimpinannya.Dapat disimpulkan bahwa untuk menemukan visi kepemimpinan Kristen, maka seseorang harus memiliki waktu untuk berdoa dan senantiasaa bergumul dan firman Allah, karena Allah adalah Sumber visi yang sejati.

Langkah berikutnya adalah mengembangkan visi kepemimpinan Kristen yang didasarkan oleh iman. ${ }^{12}$ Dalam kaitannya dengan visi, Iman, yang merupakan 'kekuatan untuk melihat yang ingin dicapai, jauh sebelum segala sesuatunya ada', adalah pengembangan dari visi dan bahkan dapat dikatakan sebagai visi ideal yang dapat menjadi riil, karena iman memberi ketepatan dan kepastian bahwa sebuah visi akan menjadi sebuah kenyataan jika visi itu dijalankan dengan penyerahan diri kepada Sang Sumber Sejati visi. Dengan iman sebuah visi dijadikan sebagai kenyataan, dan iman akan meneguhkan visi karena iman akan membuktikan bahwa visi dapat dikerjakan dan dapat dicapai. Dengan demikian visi yang dibangun di atas Iman akan menjelaskan tujuan perjalanan hidup pribadi dan organisai dan meneguhkan untuk terus berjalan ke depan guna mencapai tujuan yang mulia dan semuanya ditujukan untuk kemuliaan nama Allah.

Visi kepemimpinan Kristen yang dibangun melalui firman Allah dan doa, kemudian dikembangkan oleh Iman sehingga visi itu menjadi nyata; bukanlah visi yang harus didiamkan, melainkan harus dibagikan kepada semua orang yang dipimpinnya, karena

\footnotetext{
${ }^{10}$ Jacob J. Breedt and Cornelius J.P. Niemandt, "Relational Leadership and the Missional Church," Verbum et Ecclesia 34, no. 1 (2013), http://dx.doi.org/10.4102/ve.v34il.819.

${ }^{11}$ Tomatala, Anda Juga Bisa Menjadi Pemimpin Visioner Kiat Menemukan Dan Mengembangkan Visi Kepemimpinan, 34-35.

12Ibid., 39-41.
} 
visi kepemimpinan Kristen ibarat 'api yang membinarkan kekuatan yang menghangatkan'. Di dalam visi ada cahaya, energi, kehangatan dan kebersamaan, oleh karena itu setiap visi yang dibagikan dan dikembangkan akan menjadi milik yang dihayati oleh semua orang. Visi kepemimpinan Kristen akan menjadi kekuatan yang mengantar semua orang memasuki masa depan yang lebih baiksekaligus dapat menjawab setiap pergumulan kehidupan yang selama ini telah dipenuhi dengan tindakan-tindakan yang tidak bermanfaat bagi kehidupan. Visi kepemimpinan Kristen yang altruistik akanmemimpin kehidupan dalam perjalanan yang dinamis menuju masa depan yang baru dan lebih cerah, dan sekaligus menandakan adanya kemajuan yang terjadi dan keberhasilan yang dicapai dalam kehidupan. Perubahan hidup yang dipengaruhi oleh visi kepemimpinan Kristen bisa terjadi karena setiap pemimpin Kristen memiliki kepekaan terhadap terhadap setiap kesempatan untuk mengadakan perubahan dan sekaligus mampu menciptakan sebuah skenario masa depan yang dapat menjawab tuntutan perubahan.

Berdasarkan visi yang dimiliki oleh seorang pemimpin dapat ditegaskan bahwa tugas seorang pemimpin bukan sekadar memengaruhi orang lain guna melakukan tujuan, tetapi juga membangun orang lain sehingga orang tersebut, kelak, akan bisa menjadi pemimpin. Pemimpin yang memiliki visi akan berusaha untuk terus membangun dan berkarya guna mendatangkan keuntungan bagi banyak orang secara berkesinambungan.Pemimpin yang terus membangun adalah pemimpin yang selalu memulai kepemimpinannya dengan visi besar, sehingga akan melahirkan semangat besar yang mencipta kerja besar dan akan menghasilkan produksi besar. Dalam hubungannya dengan orang yang dipimpin, seorang pemimpin yang memiliki visi akansenantiasaa mengupayakan tiga hal penting, yaitu: ${ }^{13}$

1. Menyadari dan mengembangkan tugas kepemimpinannya yang didasarkan atas semangat melayani orang lain dengan status hamba Allah

2. Membina hubungan dengan banyak orang, teristimewa dengan yang dipimpinnya dengan menekankankan pada prinsip pengabdian

3. Mengenal setiap orang yang dipimpinnya

Dengan demikian tanggung jawab seorang pemimpin Kristen bukan sekadar membangun monumen yang bisa dikenang oleh orang, melainkan harus mampu membangun hubungan-hubungan dengan orang lain, teristimewa pengikutnya, dan pemenuhan kebutuhan pengikut demi kelancaran kinerja maupun pencapaian tujuan bersama yang ditetapkan. Tanggung jawab ini mendorong seorang pemimpin untuk terus mengembangkan diri sebagai respons terhadap anugerah Allah yang telah dianugerahkan kepada dirinya. ${ }^{14}$

\footnotetext{
${ }^{13}$ Ronny O B Worang, “"Pemimpin Yang Terus Membangun"," in Kepemimpinan Kristen Yang Membumi, ed. Nasokhili Giawa (Jakarta: YT Leadership Foundation, 2017), 155-157.

${ }^{14}$ Yakob Tomatala, Manajemen Pengembangan Sumber Daya Manusia Pemimpin Kristen, Jurnal Pendidikan Humaniora, vol. 1 (Jakarta: YT Leadership Foundation, 2003).
} 


\section{Prinsip Kepemimpinan Yesus Kristus}

Dunia masa kini dipenuhi dengan tantangan yang kompleks, yang menuntut adanya ketahanan diri dalam nilai-nilai etika dan moral yang kuat. Demikian pula dengan masalah kepemimpinan, dalam menghadapi tantangan kehidupan dunia yang sangat kompleks dibutuhkan ketahanan etika kepemimpinan yang kuat, karena harus dipahami bahwa ketahanan etika sebagai inner driving power dan moral atau expression of ethics merupakan kekuatan yang meneguhkan pemimpin, orang Kristen, dan Gereja guna menghadapi dan menjawab tantangan etika moral dalam kehidupan nyata yang dipengaruhi oleh desakan dunia. ${ }^{15}$ Dengan melihat adanya tuntutan tersebutmaka sangat perlu dikembangkan model etika bagi kepemimpinan Kristen, yaitu etika kepemimpinan Kerajaan Allah. ${ }^{16}$

Etika kepemimpinan Kerajaan Allah merupakan kekuatan etika moral yang berfungsi sebagai landasan yang menopang pemimpin, orang Kristen dan gereja untuk hidup dalam iman, etika serta moralitas yang teguh dalam menyikapi tantangan hidup global yang mengancam. Etika kepemimpinan Kerajaan Allah adalah konsep teoretis dasar yang dapat berkontribusi dalam membangun peradaban dunia dan merupakan model etika Alkitabiah yang bersifat normatif bagi sikap batin, iman, etika, moral, moralitas, etos dan etiket serta perkataan dan perilaku pemimpin dan orang Kristen, yang harus dihidupi melalui kehidupan keseharian dalam menjalankan panggilan misioner gereja di tengah dunia. Oleh sebab itu etika ini harus dibangun di atas dasar pemahaman yang Alkitabiah, sehingga dapat dijadikan sebagai tuntunan bagi kehidupan praksis yang ditandai adanya penguasaan dan pemerintahan Allah dalam kehidupan pemimpin dan orang Kristen. ${ }^{17}$

Dengan mendasarkan diri pada pemahaman di atas, dapat ditemukan beberapa aspek dari etika kepemimpinan Kerajaan Allah, antara lain: Pertama, etika ini 'memberi tempat utama bagi Allah untuk memerintah dalam kehidupan Kristen' (Mat. 6:10), ini berarti bahwa etika ini merupakan norma dan sumber serta dinamika bagi iman, sikap batin, moralitas dan perilaku pemimpin dan orang Kristen dalam kehidupan yang mereka jalani. Norma ini bersifat universal, karena itu berlaku bagi seluruh kehidupan. Aspek pertama ini menyangkut tentang aspek kosmologis. Kedua, etika inimengandung kaidah etis dan moral bagi iman dan kehidupan yang sifatnya mutlak (aspekontologis). Ketiga, etika iniberporos pada Yesus, kehidupan, karya dan ajaran-Nya di dalam Alkitab,

\footnotetext{
15Yakob Tomatala, "Etika Kerajaan Allah Sebagai Dinamika Kepemimpinan Kristen Dalam Menjawab Tantangan Zaman," in Kepemimpinan Kristen Yang Membumi, ed. Nasokhili Giawa (Jakarta: YT Leadership Foundation, 2017), 4.

${ }^{16}$ Ibid.

${ }^{17}$ Glen H Stassen and David P Gushee, Etika Kerajaan: Mengikut Yesus Dalam Konteks Masa Kini (Surabaya: Momentum, 2008), 7-11.
} 
oleh sebab itu aspek ini disebut dengan aspek Core-Truth. Keempat, etika ini bersifat wajib untuk dilakukan (epistemologis), karena merupakan perintah (imperative) yang memiliki keharusan untuk diberlakukan di mana saja di seluruh dunia oleh Gereja Yesus Kristus. Kelima, etika ini memiliki aspek teologis yang merupakan tujuan tertingginya, yaitu "kehendak dan kasih Allah" yang harus dilakukan dalam kehidupan dan kepemimpinan Kristen dalam menjalankan tugas misionernya. Kebenaran misiologis etika ini menegaskan bahwa 'Gereja diutus ke dalam dunia' untuk memberkati dunia dengan memuliakan Allah dan membawa kebaikan tertinggi, yaitu berkat keselamatan bagi diri sendiri, sesama dan dunia. ${ }^{18}$

Poros etika kepemimpinan Kerajaan Allah adalah kehidupan, karya dan ajaran Yesus Kristus, oleh karenanya etika ini merupakan penopang kehidupan kepemimpinan Kristen. Dapat dikatakan bahwa etika ini merupakan fondasi bagi etos kerja pemimpin, orang Kristen dan Gereja guna mendemonstrasikan kehidupan etis moral kudus dari kehidupan dan ajaran Yesus Kristus dalam lingkup kerja. Melalui etika inisetiap pemimpin Kristen akan memperoleh kekuatan dan ketahanan untuk hidup dan mengabdi kepada Kristus dan ketika menghadapi kritik dunia dalam segala bentuk, dan juga memberi hikmat yang menguatkan batin pemimpin dan orang Kristen, sekaligus harus mengimpartasi semangat yang berapi-api sehingga pemimpin dan orang Kristen mampu bersekutu, melayani, bersaksi, memberitakan dan membangun Gereja.

Etika kepemimpinan Kerajaan Allah tidak pernahbisa dilepaskan dengan spiritualitas kepemimpinan Kristen yang merupakan 'status, keadaan dan kadar' kerohanian Krtisten yang dibangun di atas kebenaran firman Allah, sebagai landasan normatif bagi kehidupan iman serta praktik orang percaya dalam kepemimpinan.Spiritualitas Alkitabiah bagi kepemimpinan Kristen diawali dari pengalaman Allah yang menyelamatkan dan membebaskan manusia dari kuasa dosa; oleh karenanya spiritualitas kepemimpinan Kristen selalu diisi dalam tuntunan Roh Kudus. Perlu dipahami bahwa spiritualitas kepemimpinan Kristen merupakan dinamika bagi 'identitas Kristen' yang unik, sehingga spiritualitas ini menjadi kekuatan ekstraordinari yang memberikan semangat hidup dalam komunitas dunia. Spiritualitas kepemimpinan Kristen juga memberikan gairah kehidupan dengan hasrat hidup benar dan kemauan baik untuk menghadirkan cara hidup etis moral mulia, oleh karena itu kekuatan spiritualitas Kristen akan meneguhkan pemimpin dan orang Kristen untuk senantiasaaa hidup dalam kebenaran. Sebagai dampak dari hal di atas, spiritualitas Kristen akanmendemonstrasikan 'iman yang hidup' dalam cara hidup dan perbuatan nyata yang kudus dan bebas dari kehidupan duniawi. Dengan demikian spritualitas Kristen merupakan instrumenAllah yang meneguhkan iman, etika dan moral Kristen.

${ }^{18}$ Tomatala, "Etika Kerajaan Allah Sebagai Dinamika Kepemimpinan Kristen Dalam Menjawab Tantangan Zaman," 8-10. 
Hubungan antara etika kepemimpinan Kerajaan Allah dengan spiritualitas Alkitabiahtidak dapat dipisahkan, karena etika kepemimpinan Kerajaan Allah mencerminkan sejauh mana pengaruh spiritualitas Alkitabiah dalam kehidupan pemimpin dan orang Kristen, dan spiritualitas Alkitabiah merupakan dinamika bagi praktik hidup pemimpin dan orang Kristen. Dengan demikian spiritualitas Alkitabiah, dalam hubungannya dengan etika kepemimpinan Kerajaan Allah, berfungsi sebagai 'tanda pengenal khusus' kehidupan Kristen yang ditandai oleh kualitas hidup yang spesial. Jika spiritualitas Alkitabiah merupakan hikmat penuntun bagi pikiran, sikap, perilaku, kata dan perbuatan pemimpin dan orang Kristenyang selalu mendemonstrasikan keunikan cara hidup Kristen yang dipimpin oleh Roh Kudus; maka etika kepemimpinan Kerajaan Allah merupakan nilai inti yang harus dijalankan oleh setiap pemimpin Gereja dan orang Kristen dalam menjalankan tugas misionernya. Melalui etika kepemimpinan Kerajaan Allah sikap, tindakan dan kata para pemimpin dan orang Kristen dibimbing untuk selalu selaras dengan kehendak Allah dan didasarkan atas kasih kepada Allah dan sesama.

Hal lain yang disoroti etika kepemimpinan Kerajaan Allah adalah mengenai pengembangan sikap, tindakan dan kata para pemimpin dan orang Kristen yang harus didasarkan atas iman yang benar dan keyakinan akan kesesuaian dengan kebenaran firman Allah, sejalan dengan semangat dan ajaran Gereja, hati nurani serta nilai positif masyarakat Kristen, sepadan dengan situasi langsung dalam konteks nyata, selaras dengan aspek hukum, politik dan sosial kemasyarakatan di mana perbuatan etis dilakukan, dan sesuai dengan kemauan baik sehingga menghadirkan kebenaran serta kemanfaatan bagi hidup.Dengan demikian etika kepemimpinan Kerajaan Allah merupakan instrumen dasar bagi perilaku kehidupan, dan melalui etika ini ditegaskan bahwa setiap pengambilan keputusan harus didasarkan pada keselarasan terhadap kehendak Allah dan kasih kepada Allah serta sesama. Setiap pengambilan keputusan etis oleh pemimpin dan orang Kristen hanya ditujukan untuk kemuliaan namaAllah dan harus memiliki kebaikan dan manfaat bagi diri sendiri, sesama dan orang lain, sehingga kualitas pengambilan keputusan etis akan memerlihatkan adanya kualitas etika dan moral Kristen yang melindungi kehidupan orang banyak. Hal ini menunjukkan bahwa pengambilan sebuah keputusan etis memerlihatkan cara hidup berdasarkan tanggung jawab dan kemauan baik serta keluhuran sikap pemimpin dan orang Kristen

Sebagai kesimpulan dari uraian mengenai hubungan antara kepemimpinan dan etika, maka dapat ditegaskan bahwa kepemimpinan yang dilandasi oleh etika kepemimpinan Kerajaan Allah harus diimplementasikan dalam kehidupan nyata dengan cara: ${ }^{19}$

19Ibid., 19-22. 
1. Mengutamakan terlaksananya kehendak Allah dalam setiap situasi etis

2. Mendahulukan kasih Kristus dalam setiap pengambilan keputusan etis

3. Senantiasaaa mengedepankan firman Allah dalam pengambilan keputusan etis

4. Mengedepankan keyakinan dan ajaran Gereja dalam pengambilan keputusan etis

5. Pengambilan keputusan etis harus dipertanggunjawabkan dengan hati nurani yang bersih

6. Dalam pengambilan keputusan etis pemimpin dan orang Kristen harus selalu memerhatikan dinamika situasi yang dihadapi

7. Pengambilan keputusan etis harus selalu menimbang aspek kepatutan yang selaras dengan hukum dan norma kemasyarakatan yang ada

8. Pengambilan keputusan etis selalu didasarkan atas kemauan baik yang murni yang berdasar pada kehendak Allah.

Melalui tahapan-tahapan yang telah diungkapkan di atas, maka dapat dipahami bahwa penerapan normaetika kepemimpinan Kerajaan Allah dalam kehidupan nyata, akan mendatangkan kemuliaan bagi Allah dan kebaikan besar bagi diri sendiri dan seluruh umat manusia. Untuk itu Gereja, yang keberadaannya diciptakan dan dibangun untuk memberkati dunia, harus selalu mengupayakan tanggung jawab misionernya melalui persekutuan, pelayanan, kesaksian, pemberitaan dan pembangunan manusiadengan menghadirkan shalom (Yoh. 17:18)

\section{Model Etika Kepemimpinan Kristen}

Kepemimpinan Kristen yang didasarkan atas etika kepemimpinan Kerajaan Allah dan bersumber pada pribadi Yesus hendak membangun dunia baru di tengah-tengah dunia lama, artinya orang Kristen sebagai pengikut Yesus dipanggil untuk memeragakan tanda-tanda yang menunjuk pada dunia baru yang telah dijanjikan Allah melalui hidup, karya dan pengajaran Yesus. $^{20}$ Dengan demikianpola hidup Yesus, yang menjadi pedoman bagi tumbuhnya model kepemimpinan Kristen, dapat dijadikan pedoman konkret bagi cara hidup dan perilaku kehidupan seorang pemimpin dalam hubungannya untuk mengembangkan model kepemimpinan yang efektif dan efisien. ${ }^{21}$

Dalam bagian ini, secara khusus penulis akan mencoba untuk menghadirkan lima buah panduan mengenai kepemimpinan Yesus yang memengaruhi perilaku sosial orang Kristen, karena kepemimpinan Yesus tidak akan pernah bisa dilepaskan dari nilai-nilai sosial yang akan ditumbuhkan sebagai bentuk konsekuensi ketika kepemimpinan itu dilakukan. Kelima panduan tersebut adalah:

${ }^{20}$ Yakob Tomatala, Kepemimpinan Yang Dinamis (Jakarta: YT Leadership Foundation \&, 2005), 43.

${ }^{21}$ John Bolt, "The Imitation of Christ as Illumination for the Two Kingdoms Debate," Calvin

Theological Journal 48, no. 1 (2013): 33. 


\section{Kepemimpinan Yesus Kristus adalah Kepemimpinan Yang Mematahkan Lingkaran}

\section{Setan Yang Terdiri Atas Kekerasan Dan Pembalasan}

Riwayat Yesus tidaklah bersifat tenteram dan sentosa; bahkan selalu terancam oleh kekerasan. Betapa seringnya Injil mengisahkan tentang hasrat para Imam, Farisi, Saduki dan kelompok lainnya untuk membinasakan Yesus. Bahkan seorang raja Herodes pun berhasrat untuk membunuh dan menyingkirkan Yesus. Situasi yang demikian menggambarkan suasana kekerasan yang sudah sangat lazim terjadi pada konteks zaman itu. Karena memang zaman itu merupakan zaman kerusuhan, di mana pada zaman itu bangsa Yahudi sedang mengalami penjajahan dan pemerasan dari bangsabangsa asing yang bertindak sangat kejam terhadap mereka. Dana kekerasan ini semakin diperparah dengan tindakan balasan yang dilakukan oleh kelompok pejuang bangsa Yahudi, yaitu aliran Zelot, yang terdiri dari orang-orang Makabe, di mana mereka melakukan tindakan kekerasan guna melawan penjajahan bangsa asing. Karena antara penguasa penjajah dan yang dijajah terjadi balas membalas, maka 'lingkaran setan' kekerasan dilestarikan.

Dalam masa Yesus berkarya, kebencian terhadap musuh dianggap sebagai kewajiban agamawi, sampai-sampai Yesus pernah berkata, "Kamu telah mendengar firman..., bencilah musuhmu" (Mat. 5:43). Sikap ini justru dianjurkan oleh kaum Eseni dan aliran Zelot, sesuai dengan peribahasa Rabinis, "Siapa saja yang menumpahkan darah seorang kafir adalah bagaikan orang yang memersembahkan kurban." ${ }^{22 B a g i}$ Yesus, yang hidup di zaman kekerasan seperti itu, 'lingkaran setan' kekerasan semacam ini harus dihapuskan. Satu-satunya cara untuk mematahkan lingkaran setan itu adalah dengan memasukkan unsur baru ke dalam situasi yang serba kacau tersebut. Unsur baru yang dimasukkan melalui pola kepemimpinanYesus adalah penolakan untuk menjadi musuh terhadap siapa pun. Itu tidak berarti bahwa Yesus tidak sadar akan perseteruan yang mengepungnya atau bahwa Ia segan mencela tingkah laku atau sikap para lawanNya. Akan tetapi Ia menolak untuk membenci orang-orang yang membenci-Nya dan sekaligus menolak untuk membalas dendam. Sebaliknya Yesus memimpin orang untuk masuk dalam sikap baru, yaitu 'Kasihilah musuhmu'.

Jika model kepemimpinan Yesus yang berusaha mematahkan belenggu kebencian dengan cara menolak untuk membenci diberlakukan, maka setidak-tidaknya lingkaran setan kebencian dan dendam akan dipatahkan, karena hal untuk saling membalas sudah tidak berjalan, akibat salah satu pihak tidak mau untuk melakukan hal yang sama, yaitu saling membalas. Boleh jadi kebencian dan kekerasan tetap dilangsungkan oleh pihak lawan tetapi putaran lingkarang kebencian itu sudah diperlambat, apalagi kalau sikap positif yang dianjurkan Yesus juga dituruti, yaitu, "Berbuatlah baik kepada orang yang

22Fletcher, Lihatlah Sang Manusia: Suatu Pendekatan Pada Etika Kristen Dasar, 264. 
membenci kamu, mintalah berkat bagi orang yang mengutus kami; berdoalah bagi orang yang mencaci kamu" (Luk. 6:27-28). Jelaslah di sini bahwa kepemimpinan Yesus yang mematahkan lingkaran kekerasan harus dimulai dengan mengatasi kekerasan yang ada di dalam diri para pemimpin itu sendiri. Karena kekerasan lahiriah bersumber pada sikap-sikap batin: hati yang keras dan tanpa ampun, yang lekas marah, yang mementingkan diri sendiri (egoisme), angkuh dan agresif, yang kesemuanya ada sebagai sebuah hasrat untuk menguasai orang lain. Semua sikap negatif ini harus terlebih dahulu dihilangkan oleh para pemimpin Kristen, agar para pemimpin Kristen terbebas dari hasrat untuk menekan dan menguasai orang lain. Segala macam tindak dan sikap kekerasan harus disingkirkan dari dalam diri seorang pemimpin Kristen, seperti halnya Yesus yang telah bebas dari tindak dan sikap kekerasan baik secara lahir maupun batin. Asal dari semua ketenangan ini bersumber pada pengandalan diri-Nya kepada Allah (1 Petr. 2:23). Pengandalan kepada kemurahan dan kebaikan Allah melenyapkan ketakutan di hadapan orang lain, serta keperluan untuk membela diri secara fisik maupun psikis. Inilah panduan pertama yang harus ditumbuhkan dan dimiliki oleh setiap pemimpin Kristen yang mendasarkan model kepemimpinannya pada kepemimpinan Yesus.

\section{Kepemimpinan Yesus Kristus Adalah Kepemimpinan Yang Menolak Pola Penguasaan Ketundukan Sebagai Patokan Bagi Hubungan Antar Manusia.}

Tidak dapat disangkal bahwa dalam pola relasional sosial secara umum, berlaku hukum sebagai berikut, 'yang kuat berkuasa, yang lemah tunduk. Pola ini seakan-akan merupakan hukum kodrati yang berlaku terus menerus sepanjang sejarahmanusia, ditambahlagi mentalitas masing-masing pihak biasanya saling mengimbangi, yaitu pola ketundukan diterima bukan hanya oleh pihak yang berkuasa, melainkan pihak yang lemah pun lazim menerima keadaan sub-ordinasi mereka sebagai sesuatu yang wajar. Namun pola yang lumrah ini dipersoalkan oleh Yesus. Dalam Markus 10:42-43, Yesus mengatakan bahwa sikap para murid tidaklah harus sama dengan sikap pemerintah yang memerintah dengan tangan besi. Bagi Yesus, seorang pemimpin yang besar adalah seseorang yang mau menjadi pelayan bagi sesame, dan hal ini diberlakukan umum oleh Yesus, sehingga kepemimpinan Yesus yang hendak mematahkan pola dominasi - subordinasi bukan sekadar ditujukan kepada para pemimpin kafir tetapi juga kearah para pemimpin bangsanya sendiri, yang memberlakukan sistem pemerintahan dunia.

Kepemimpinan Yesus yang menekankan mengenai 'yang terbesar adalah yang melayani' itu terdapat sampai lima kali dalam Injil Sinoptik (Mat. 20:26 dan 23:11; Mrk. 9:35 dan 10:43; Luk. 22:26) dan dalam konteks yang berbeda-beda, ada yang dalam konteks untuk menghentikan pertengkaran para murid, ada yang dalam konteks jawaban Yesus terhadap sikap orang, dan dalam konteks jawaban mengenai permohonan untuk menjadi yang lebih utama. Ini berarti bahwa kepemimpinan Yesus Kristus hendak membongkar pola kekuasaan dalam kepemimpinan dan 
menggantikannya dengan pola pelayanan dalam model kepemimpinan gayabaru, yaitu: daripada menguasai, pihak yang kuat dihimbau untuk melayani; karena sikap seperti itu adalah sikap yang lebih terhormat. Dalam hal ini Yesus bukan sekadar mengatakan dalam ajaran, melainkan juga menjadi perwujudan sempurna dari mentalitas gaya baru ini. Yesus memraktikkan kepemimpinan gaya baru yang sangat berbeda dengan gaya kepemimpinan para pemimpin saat itu yang 'gila hormat', terkhusus ketika Yesus melakukan tindakan simbolis dalam perjamuan malam terakhir. Dalam peristiwa itu Yesus membasuh kaki para muridNya, dan ini berarti Yesus sedang mengajarkan model kepemimpinan gayabaru yaitu seorang pemimpin sebagi pelayan.

Tentu gaya yang baru itu tidak berarti bahwa pimpinan tidak diperlukan lagi. Dalam model kepemimpinan Yesus ini tidak diragukan lagi siapa pemimpinnya, tetapi dalam model ini ditekankan cara memimpin yang baru, yaitu melalui pelayanan dan dengan penuh penghargaan atas martabat pengikutnya masing-masing. Kewibawaan yang ditumbuhkan bukan kewibawaan otoriter, melainkan kewibawaan yang dibangun berdasarkan kerendahan hati.

\section{Kepemimpinan Yesus Kristus adalah Kepemimpinan yang Menembus Kesetiakawanan yang Bersifat Sempit}

Yang dipersoalkan dalam panduan ini bukan mengenai keterikatan alami pada ikatan-ikatan primer, seperti keluarga, kelompok sahabat akrab, suku bangsa dan lainlain. Yang dipersoalkan adalah kecenderungan untuk memutlakkan kesetiaan pada kelompok-kelompok alami tersebut sedemikian rupa, sehingga orang tertutup terhadap orang lain dan golongan lain yang berada 'di luar' mereka. Kecenderungan untuk memisahkan antara 'kita' dengan 'mereka', untuk mendirikan tembok pemisah antara in-group dan out-group, yang membawa ke arah sikap 'kita pasti benar, mereka pasti salah'. Penghinaan terhadap golongan lain memupuk rasa super bagi diri atau golongan sendiri, dan akhirnya kesetiaan yang berlebihan kepada golongan sendiri mengakibatkan timbulnya keangkuhan, kefanatikan, kebencian, bahkan ulah yang tidak berperikemanusiaan terhadap golongan lain, entah dalam skala yang kecil maupun dalam skala yang besar.

Pada dasarnya ada dua jenis kesetiakawanan, yaitu yang tertutup (eksklusif) yang batu ukurannya adalah: perbedaan antara 'mereka' dan 'kita'; dan yang terbuka (inklusif) yang batu ukurannya adalah apakah 'mereka' membutuhkan 'kita', maksudnya membutuhkan pengertian serta pertolongan dari pihak 'kita', yang terbuka juga dalam arti mengenali pada pihak mereka nilai-nilai kebudayaan atau pun moral yang sepantasnya dihargai. Keterbukaan ini didasari atas kesadaran akan kemanusiaan yang dimiliki bersama dengan mereka dan akhirnya atas kesadaran akan persamaan segala orang di hadapan Allah. Melalui pola kepemimpinan ini, Yesus mau mengkonkretkan 
segala ajaran-Nya, yaitu kasih terhadap sesama yang membutuhkan pertolongan atau persahabatan. Soal yang pokok adalah, apakah setiap orang Kristen yang menjadi pemimpin bersedia dan siap berinteraksi dengan siapa pun, entah itu orang yang dipimpin atau kolega lainnya, atas dasar kemanusiaan, tanpa memandang bulu, bangsa atau ideologinya.

Model kepemimpinan Yesus dalam pedoman ketiga ini menekankan bahwa seorang pemimpin mutlak harus memiliki nilai kemanusiaan jika sedang memimpin. Dengan nilai kemanusiaan yang dimiliki, seorang pemimpin akan bisa menerima siapa pun yang dipimpinnya, tanpa harus didasarkan atas unsur-unsur premordialisme. Dia juga tidak akan pandang bulu dalam memerlakukan setiap orang yang dipimpinnya, sehingga dia akan selalu bersikap adil dalam setiap tindakannya.

\section{Kepemimpinan Yesus Kristus adalah Kepemimpinan Yang Mengenyampingkan Kekuasaan, Kejayaan dan Gengsi Sebagai Pertanda Pemerintahan Allah.}

Dalam pandangan umum, seharusnya ketika Yesus hendak memersiapkan jalan bagi pemerintahan Allah, Ia harus memerhitungkan kenyataan di dunia ini secara realistis, sehingga dalam kepemimpinan-Nya, sepatutnya Ia mencari dukungan dari aneka lapisan masyarakat, menambah dana cadangan, memelihara hubungan dengan pihak yang berpengaruh dan berkuasa, serta melembagakan cita-cita-Nya dalam suatu struktur sosial yang mantap dan lestari. Seharusnya kepemimpinan yang dijalani-Nya membangun suatu organisasi dengan susunan yang teratur serta peraturan tegas, agar dapat bersaing dengan gerakan-gerakan yang lain untuk meraih kuasa dan pengaruh, karena di dunia ini gengsi dan kejayaan menjadi sebuah kekaguman bagi semua orang, dan nampaknya semua ini adalah wajar-wajar saja. Namun yang dilakukan Yesus justru kebalikan dari semua itu. Justru Yesus, dalam mempersipakan kedatangan Kerajaan Allah, membangun kepemimpinan-Nya di tengah-tengah rakyat jelata, dan model kepemimpinan yang dibangun-Nya adalah selalu mendahulukan kaum miskin. Dana dan organisasi tidak dihiraukan-Nya dan tunjangan dari pihak yang berpengaruh sama sekali tidak dicari-Nya. Gaya hidup dan gayakepemimpinan Yesus menjadi sebuah gaya yang tidak wajar, bahkan menjadi batu sandungan bagi orang sepanjang masa. Sehingga tidaklah mengherankan apabila hidup-Nya berakhir di kayu salib.

Pertanyaan yang timbul adalah, "Mengapa Yesus mengutamakan/mendahulukan kabar baik bagi orang miskin dan bukan kabar baik bagi sekalian orang?" Agaknya prinsip kepemimpinan Yesus yang menempatkan orang miskin sebagai prioritas bertumpu pada tradisi seluruh Perjanjian Lama tentang Allah yang memihak pada golongan yang rendah dan lemah. Bagi orang-orang yang tidak dapat membela dirinya sendiri, Allah menunjukkan diri-Nya sebagai Pengayom mereka, maka dengan sengaja Yesus melanjutkan aliran profetis ini dengan menerapkan pada masa-Nya sendiri, dan menurut perkataan Nabi Yesaya, Ia diutus dan diurapi oleh Roh Allah justru 'untuk 
menyampaikan kabar baik kepada orang-orang miskin' (Luk. 4:18). Namun hal ini jangan hanya berhenti sampai di sini, perlu langkah yang lebih jauh lagi.

Jika diperiksa dengan teliti keinginan para pendengar Injil tentang Yesus yang mengumumkan 'kabar baik bagi sekalian orang', maka apa yang benar-benar sedang dituntut adalah supaya Yesus memusatkan pada unsur-unsur spiritual dari pemerintahan Allah sambil mengambil sikap netral terhadap segi-segi sosial. Akan tetapi mengingat keadaan sosial zaman Yesus yang ditandai oleh polarisasi antara minoritas yang mampu dan mayoritas melarat, apakah akibat dari sikap netral tersebut? Dalam konteks ini, dengan tegas Yesus menolak untuk berpihak pada yang kuat, yang merupakan kelompok minoritas, dan Yesus justru dengan terang-terangan memihak yang melarat, yang merupakan kelompok mayoritas. Ini menunjukkan bahwa tidak ada sebenarnya netralitas dalam sebuah sikap kepemimpinan Yesus. Sikap kepemimpinan Yesus adalah sikap yang memihak. Dengan memihak yang rendah, Yesus menyingkapkan dan menarik perhatian pada keadaan yang tidak adil. Oleh sebab itu, sikap netral bukanlah bagian dari keadilan pemerintahan Allah dan sekaligus tidak menjadi bagian dari model kepemimpinan Yesus.

Patut ditegaskan di sini, bahwa meskipun Yesus selalu berpihak pada orang-orang miskin, melarat dan tertindas, sehingga kepemimpinan-Nya adalah kepemimpinan yang memihak, namun bukan berarti Yesus menutup pintu terhadap lawan-lawan-Nya. Mereka masih diajak masuk atas dasar yang sama dengan kaum pinggiran, yaitu melalui pertobatan dan kesediaan untuk mengakui kehadiran pemerintahan Allah dalam pola kepemimpinan Yesus.

\section{Kepemimpinan Yesus Kristus adalah Kepemimpinan yang Menisbikan Segala kemutlakan Buatan Manusia Serta Bergumul Melawan Kuasa Kejahatan}

Tema panduan ini dapat diringkaskan dalam tanggapan Yesus kepada Iblis di padang gurun, "Ada tertulis, "Engkau harus menyembah Allah, dan hanya kepada Dia sajalah engkau berbakti" (Mat. 4:10b). Umumnya orang memahami ucapan ini sematamata dari sudut peribadatan, tetapi dalam konteks pencobaan Yesus, pernyataan ini pasti menolak segala kekuasaan yang bertentangan dengan Allah dan kehendak-Nya, bukan hanya kekuasaan keagamaan tetapi juga kekuasaan sosial politik. Tanggapan Yesus mengingatkan pada ungkapan yang terdapat dalam Keluaran 20:3, "Jangan ada padamu allah lain di hadapanKu". Ungkapan ini mau mengatakan bahwa keberadaan allah lain dan kekuasaan lain tidak diingkari, yang diperintahkan adalah supaya di tengah-tengah kuasa-kuasa yang lain, kesetiaan yang utama diberikan semata-mata hanya kepada kekuasaan yang membawa Israel ke luar dari perbudakan Mesir.Jadi hukum pertama dalam hukum Taurat itu mencerminkan suatu keadaan yang ditandai pertentangan kuasa-kuasa yang di antaranya kuasa Yahweh-lah yang paling unggul. 
Yesus juga berjuang dalam keadaan yang ditandai perlawanan dan konflik, namun bagiNya selain Allah tidak ada kekuasaan atau ideologi atau pranata yang layak menerima pengabdian-Nya; bukan Kaisar, bukan Mamon, bukan pula bangsa terpilih, Bait Allah maupun Taurat, melainkan Allah itu sendiri. Dengan demikian kepemimpinan Yesus adalah kepemimpinan yang menisbikan kemutlakan hukum Taurat atas nama kehendak Allah, sehingga Ia harus mati. Yesus juga menisbikan kesaktian Bait Allah atas nama penyembahan 'dalam Roh dan kebenaran', sehingga Ia diserahkan kepada Pilatus dan para Imam. Kepemimpinan Yesus juga menisbiskan gagasan bangsa terpilih atas nama Kerajaan Allah yang terbuka terhadap segala bangsa, sehingga bangsa-Nya sendiri berteriak, “Salibkan Dia!” Kepemimpinan Yesus juga menisbikan dewa Mamon, atas nama Bapa yang memberikan segala yang baik, akibatnya golongan yang kaya dan terkemuka bersekongkol untuk membunuh Dia. Akhirnya, kepemimpinan Yesus menisbikan wewenang Kaisar atas nama Kerajaan yang bukan dari dunia ini, sehingga Ia disalibkan demi nama keamanan kekaisaran Romawi.

Rumusan-rumusan di atas memerlihatkan 'medan pertempuran' tempat Yesus meneruskan pergumulan-Nya, dan dalam model kepemimpinan yang dikembangkan Yesus dengan tegas melarang supaya setiap pemimpin tunduk mutlak pada aturanaturan yang dibuat manusia. Kemutlakan ketundukan hanya diberlakukan bagi peraturan Allah yang telah ditetapkan dalam setiap ajaran Yesus Kristus.

\section{Kesimpulan}

Dalam kehidupan ini ada dua jenis pemimpin, yaitu mereka yang berhasil menjalankan tugas kepemimpinannya dengan baik dan dapat mengakhirnya dengan baik pula (finishing-well) dan mereka yang tidak dapat menjalankan tugas kepemimpinannya dengan baik, serta tidak ada pemimpin baru yang dihasilkan untuk meneruskan karyanya, dan pada akhirnya berakhir dengan menyedihkan.Dengan demikian, pada hakikatnya kepemimpinan bukanlah ditentukan oleh besarnya lembaga yang dipimpin dan tingginya posisi atau jabatan yang dipegang, serta seberapa besar kekuasaan yang ada di dalam genggaman seseorang, namun ditentukan oleh seberapa besar pengaruh yang dapat diberikan kepada orang-orang yang dipimpin dan bagaimana ia membangun hubungan yang berkualitas dengan orang-orang yang ada di sekitarnya.Memimpin seperti Yesus adalah memimpin dengan berbasiskan teladan kehidupan Yesus. Kebenaran tentang kepemimpinan Yesus Kristus ini menunjuk pada hakikat hidup, cara hidup, sifat, sikap dan kebiasan-Nya yang didemonstrasikan melalui pikiran, perasaan, kehendak dan kata serta tindakan-Nya yang berkualitas, oleh sebab itu Yesus adalah pemimpin yang menampilkan keunggulan karakter dalam kepemimpinan-Nya. Model kepemimpinan Yesus adalah kepemimpinan yang berpusat pada hati nurani. Karena itu seorang pemimpin harus memiliki hati yang bersedia, hati yang berkobar, hati yang bijaksana, hati yang sempurna, hati yang lembut, hati yang 
setia, hati yang tabah, hati yang gembira, hati yang baru, hati yang berpengertian, hati yang terencana,dan hati yang mengampuni. Dengan memiliki hati yang baik seperti di atas, maka seorang pemimpin akan memiliki belas kasih, dan ia akan menjadikan dirinya sebagai pembebas dan pengayom mereka yang tersesat. Ia pun akan menjadi gembala yang baik bagi setiap orang yang dipimpinnya; dan memiliki kelemahlembutan serta kerendahan hati, sehingga apa yang diperbuatnya selalu berhasil, efektif dan efisien.

\section{Referensi}

Bolt, John. "The Imitation of Christ as Illumination for the Two Kingdoms Debate." Calvin Theological Journal 48, no. 1 (2013): 6-34.

Breedt, Jacob J., and Cornelius J.P. Niemandt. "Relational Leadership and the Missional Church." Verbum et Ecclesia 34, no. 1 (2013). http://dx.doi.org/10.4102/ve.v34il.819.

Fletcher, Verne H. Lihatlah Sang Manusia: Suatu Pendekatan Pada Etika Kristen Dasar. Jakarta: BPK Gunung Mulia, 2007.

Frunză, Sandu. "Ethical Leadership, Religion and Personal Development in the Context of Global Crisis." Journal for the Study of Religions and Ideologies 16, no. 46 (2017): 316.

Maiaweng, Peniel S D. “"Kebesaran Seorang Pemimpin, Suatu Refleksi Terhadap Matius 20:20-28"." In Kepemimpinan Kristen Yang Membumi, edited by Nasokhili Giawa. Jakarta: YT Leadership Foundation, 2017.

Nuhamara, Daniel. “"Pentingnya Karakter Kepemimpinan Dalam Organisasi”.” In Kepemimpinan Kristen Yang Membumi, edited by Nasokhili Giawa. Jakarta: YT Leadership Foundation, 2017.

Reddy, Asi Vasudeva, and A. V.S. Kamesh. "Integrating Servant Leadership and Ethical Leadership." Ethical Leadership: Indian and European Spiritual Approaches. London: Palgrave Macmillan, 2016. https://doi.org/10/1057/978-1-137-60194-0_7. Stassen, Glen H, and David P Gushee. Etika Kerajaan: Mengikut Yesus Dalam Konteks Masa Kini. Surabaya: Momentum, 2008.

Tomatala, Yakob. Anda Juga Bisa Menjadi Pemimpin Visioner Kiat Menemukan Dan Mengembangkan Visi Kepemimpinan. Jakarta: YT Leadership Foundation, 2005.

___. "Etika Kerajaan Allah Sebagai Dinamika Kepemimpinan Kristen Dalam Menjawab Tantangan Zaman." In Kepemimpinan Kristen Yang Membumi, edited by Nasokhili Giawa. Jakarta: YT Leadership Foundation, 2017.

—_- Kepemimpinan Yang Dinamis. Jakarta: YT Leadership Foundation \&, 2005. ___. Manajemen Pengembangan Sumber Daya Manusia Pemimpin Kristen. Jurnal 
Pendidikan Humaniora. Vol. 1. Jakarta: YT Leadership Foundation, 2003.

_-_ Memimpin Seperti Yesus Kristus: Kepemimpinan Yang Par-Ekselens. Jakarta: YT Leadership Foundation, 2010.

- - Par-Excellence Leadership: Memimpin Seperti Yesus Kristus. Jakarta: YT Leadership Foundation, 2013.

Worang, Ronny O B. “"Pemimpin Yang Terus Membangun”.” In Kepemimpinan Kristen Yang Membumi, edited by Nasokhili Giawa. Jakarta: YT Leadership Foundation, 2017. 